\begin{tabular}{|l|l|l||}
\hline \multicolumn{2}{|c|}{ PublisherInfo } \\
\hline \hline PublisherName & $:$ & BioMed Central \\
\hline \hline PublisherLocation & $:$ & London \\
\hline \hline PublisherImprintName & $:$ & BioMed Central \\
\hline \hline
\end{tabular}

\title{
Regulating p53
}

\begin{tabular}{|l|l|l||}
\hline \multicolumn{2}{|c|}{ ArticleInfo } \\
\hline \hline ArticleID & $:$ & 4189 \\
\hline \hline ArticleDOI & $:$ & $10.1186 /$ gb-spotlight-20010829-01 \\
\hline \hline ArticleCitationID & $:$ & spotlight-20010829-01 \\
\hline \hline ArticleSequenceNumber & $:$ & 260 \\
\hline \hline ArticleCategory & $:$ & Research news \\
\hline \hline ArticleFirstPage & $:$ & 1 \\
\hline \hline ArticleLastPage & $:$ & 2 \\
\hline \hline & & RegistrationDate : 2001-08-29 \\
ArticleHistory & $:$ & OnlineDate $\quad$ 2001-08-29 \\
\hline \hline ArticleCopyright & $:$ & BioMed Central Ltd2001 \\
\hline \hline ArticleGrants & $:$ & \\
\hline \hline ArticleContext & $:$ & 130592211 \\
\hline \hline
\end{tabular}


MDM2 is an E3 ubiquitin ligase that regulates the activity of p53 by controlling degradation of the p53 protein, as a result of differential addition of ubiquitin. In the Advanced Online Publication of Nature Genetics, Parant et al. report the phenotype of mice lacking the recently cloned MDM2-related protein MDM4 (DOI:10.1038/ng714). They show that $m d m 4$-null mice die at embryonic day 7.5-8.5. Analysis of the incorporation of the nucleotide analogue BrdU and TUNEL staining for apoptotic cells showed that, unlike mdm2-deficient embryos, death appears to be due to reduced cell proliferation and not induction of apoptosis. As with the $m d m 2$-deficient lethality, loss of Trp 53 rescued the lethal phenotype of $m d m 4$-null embryos. Thus, in vivo the MDM2 and MDM4 proteins are non-overlapping regulators of p53 function.

\section{References}

1. Nature Genetics, [http://genetics.nature.com]

2. MDMX: a novel p53-binding protein with some functional properties of MDM2

3. Rescue of early embryonic lethality in mdm2-deficient mice by deletion of p53. 